\title{
Short communication: Variability in milk urea nitrogen and dairy total mixed ration composition in the northeastern United States
}

\author{
A. N. Hristov, ${ }^{* 1}$ M. Harper, ${ }^{*}$ J. Oh, ${ }^{*}$ F. Giallongo, ${ }^{*}$ J. C. Lopes, ${ }^{*}$ G. Cudoc, $†$ J. Clay, $\ddagger$ R. Ward,, \\ and L. E. Chase\# \\ *Department of Animal Science, The Pennsylvania State University, University Park 16802 \\ †Dairy One Coop. Inc., Ithaca, NY 14850 \\ ‡Dairy Records Management Systems, Raleigh, NC 27603 \\ §Cumberland Valley Analytical Services, Maugansville, MD 21742 \\ \#Department of Animal Science, Cornell University, Ithaca, NY 14850
}

\begin{abstract}
The main objective of this survey was to examine variability in milk urea nitrogen (MUN) for Dairy Herd Improvement Association (DHIA) herds in the northeastern United States (the Northeast), examine trends in dairy cow diet composition, and determine potential relationships for MUN and diet composition. Trends in milk fat and protein concentrations, milk yield, days in milk on test day, and lactation number of the cows were also evaluated. The data set for the survey included 10,839,461 DHIA dairy cow records from 2004 to 2015 for 13 states (CT, DE, MA, MD, ME, NH, NJ, NY, PA, RI, VA, VT, and WV) and was retrieved from Dairy Records Management Systems (Raleigh, NC). Average (across states and years) milk yield, milk fat, and milk protein were $31.6 \pm 0.24 \mathrm{~kg} / \mathrm{d}, 3.85 \pm 0.021 \%$, and $3.13 \pm 0.013 \%$, respectively. No obvious trends were observed for milk fat or protein content, but milk yield steadily increased during the survey period. Milk urea $\mathrm{N}$ concentration averaged $13.3 \pm 0.13 \mathrm{mg} / \mathrm{dL}$, with no obvious or consistent trends. Examination of variability in dairy feed cost and all milk price for the Northeast indicated that high MUN generally coincided with high feed cost and high milk price. For the diet composition survey, 9,707 records of total mixed ration (TMR) analyses, unrelated to the milk composition data set, from the Cumberland Valley Analytical Service (Maugansville, MD) database were examined. Concentration of TMR crude protein (CP) decreased from $17.1 \%$ in 2007 to $16.4 \%$ in 2015 , but there was not an obvious trend in soluble protein concentration. Concentration of TMR neutral detergent fiber (NDF) and 24-h in vitro NDF degradability declined steadily during the survey period and was accompanied by a steady in-
\end{abstract}

\footnotetext{
Received March 23, 2017.

Accepted October 27, 2017.

${ }^{1}$ Corresponding author: anh13@psu.edu
}

crease in TMR starch concentration. Examination of these unrelated data sets revealed lack of correlation between MUN and diet chemical composition. Thus, we conclude that individual cow MUN in Northeast dairy herds fluctuated between 2004 and 2015. It appeared that MUN followed variability in feed cost; however, ration feed ingredient data were not available to better define the reasons for the variations in MUN.

Key words: milk urea nitrogen, diet composition, northeastern United States, dairy cow

\section{Short Communication}

Diet composition and nutritional strategies are powerful tools for manipulating milk composition in dairy cows. Some milk components, such as lactose, are less variable than others, such as milk fat, protein, and MUN, which are more responsive to dietary interventions (Jenkins and McGuire, 2006). Individual cow or bulk tank milk samples are regularly collected on dairy farms, and MUN is used for monitoring dietary $\mathrm{N}$ adequacy in dairy rations. The relationship between dietary protein intake and BUN has long been established (Lewis, 1957). In turn, a strong relationship $\left(\mathrm{R}^{2}\right.$ $=0.84$ ) between BUN and MUN in dairy cows was demonstrated by Broderick and Clayton (1997). These relationships have been the basis for using MUN as a predictor of $\mathrm{N}$ excretion and utilization efficiency in dairy cows (Broderick and Clayton, 1997; Jonker et al., 1998; Nousiainen et al., 2004) and ammonia emissions from manure (Burgos et al., 2010; van Duinkerken et al., 2011; Powell et al., 2014). One of the most effective tools for decreasing urinary $\mathrm{N}$ losses and ammonia emissions from dairy manure is a reduction in dietary protein concentration (Hristov et al., 2011, 2015). Decreasing dietary protein, however, may result in loss of production or decreased milk components (Lee et al., 2012; Giallongo et al., 2016), and dairy producers and their nutritionists are cautious in implementing these 
changes. It is unclear to what extent, if any, the dairy industry in the northeastern United States (hereafter, the Northeast) is utilizing diets with decreased protein concentration. More than $70 \%$ of the commercial dairies surveyed by Jonker et al. (2002) were overfeeding protein. According to the current dairy NRC (2001) model, the MP needs of a dairy cow producing $45 \mathrm{~kg}$ of milk/d can be met with a balanced diet containing $16 \% \mathrm{CP}$, which is lower than typical CP concentrations reported for commercial dairy farms in several surveys (Hristov et al., 2006; Castillo et al., 2012; Higgs et al., 2012). In a recent on-farm project in Pennsylvania, however, we observed trends for decreased CP in lactating diets (Weeks et al., 2015), similar to those reported recently for Canadian farms by Sova et al. (2014). Therefore, we conducted a survey of DHIA records and dairy TMR samples submitted to a commercial feed analysis laboratory with the objective of investigating trends in milk components, with emphasis on MUN, in relation to TMR chemical composition for commercial dairy farms in the Northeast. Our hypothesis was that $\mathrm{CP}$ concentration in dairy diets has been decreasing in the Northeast and this would be reflected in decreasing MUN in milk samples from the region.

The data set for this survey included 10,839,461 DHIA dairy cow records from 2004 to 2015 for 13 states (CT, DE, MA, MD, ME, NH, NJ, NY, PA, RI, $\mathrm{VA}, \mathrm{VT}$, and $\mathrm{WV}$ ) and was retrieved from the Dairy Records Management Systems (Raleigh, NC). Data for lactation number, DIM on test day, milk yield $(\mathrm{kg} / \mathrm{d})$, and milk fat (\%), protein (\%; information on crude vs. true protein was not available), and MUN (mg/dL) contents were collected. The data set included all dairy cattle breeds. Data for states and years with too few observations were removed from the analysis; a total of 327 observations were removed. As an example, there was 1 observation for Delaware in 2013 and 6 observations in 2014; these observations were removed from the data set.

Trends in dairy diet composition in the Northeast were also examined to investigate relationships with milk components. Total mixed ration analysis data were retrieved from Cumberland Valley Analytical Services' database (CVAS; Maugansville, MD). Only TMR samples submitted from Northeast states between 2007 and 2015 with NDF concentration between 25 and $40 \%$ (considered a dairy TMR) were included in the survey. A total of 9,707 records were included in the data set. It is noted that the feed composition data set was unrelated to the milk composition data set. Diet composition data used in the analysis included CP, soluble protein, NDF, starch, NFC, and 24-h NDF degradability. Some analyses had fewer observations, with the fewest observations being for 24-h NDF degradability ( $\mathrm{n}=3,308)$. Most of the TMR analyses were by near infrared (NIR) spectroscopy versus wet chemistry (details at http://www.foragelab.com/Lab -Services/Forage-and-Feed/Lab-Procedures; accessed Feb. 19, 2017). Of the samples that entered the CVAS database, $63.5 \%$ were analyzed by NIR and $63.5 \%$ by wet chemistry. Trends in dairy feed cost (University of Wisconsin Dairy Marketing and Risk Management Program; http://future.aae.wisc.edu/data/monthly _values/by_area/2401?grid = true; accessed Feb. 20, 2017) and milk price (NASS, 2017) were also investigated. Descriptive statistics and Pearson correlation analysis of averaged by year milk and TMR composition, dairy feed cost for Pennsylvania and the United States, and Northeast milk price data were carried out using the MEANS and CORR procedures, respectively, of SAS software (version 9.4, 2002-2012; SAS Institute Inc., Cary, NC). Outliers were removed with the REG procedure of SAS based on an absolute studentized residual value $>3$. Dietary nutrient concentration data were fitted to a linear model using Sigma Plot 13.0 (SPSS Inc./IBM Corp., Chicago, IL).

Lactation, milk yield, and composition data are presented in Table 1. Average parity of the cows included in the survey was $2.3 \pm 0.03$ lactations, and average DIM on test day was $176 \pm 5.8$ d. Except in 2004, which was an outlier with an average DIM of $116 \pm 4.0$ d, the range in DIM was from 171 (2013) to 191 (2008) d. Average milk yield, milk fat, and milk protein were $31.6 \pm 0.24 \mathrm{~kg} / \mathrm{d}, 3.85 \pm 0.021 \%$, and $3.13 \pm 0.013 \%$, respectively. Milk yield for Northeast DHIA herds tended to increase slightly during the survey period, particularly between 2013 and 2015 (highest milk yield was in 2004 but this was a result of the lower DIM in that year). No obvious trends were observed in milk fat or protein content. Milk urea N concentration averaged $13.3 \pm 0.13 \mathrm{mg} / \mathrm{dL}$, with no obvious or consistent trends; MUN increased from 2004 to 2008, declined in 2009 through 2011, increased to its highest concentrations in 2012-2013, and then declined again in 2014 and 2015 (Figure 1a).

Concentration of dietary $\mathrm{CP}$ in Northeast TMR samples submitted to CVAS, a data set unrelated to the milk composition data set discussed above, steadily decreased (linear fit, $\mathrm{R}^{2}=0.85, P<0.001 ; \mathrm{n}=9$ ) from $17.1 \%$ in 2007 to $16.4 \%$ in 2015 (Table 2); TMR $\mathrm{CP}$ averaged $16.4 \pm 0.08$ in $2016(\mathrm{n}=429$; data not shown in table). We did not detect an obvious trend in TMR soluble protein concentration, which averaged $6.3 \pm 0.09 \%$ (DM basis) for the survey period; diet RDP or RUP data were not available. Concentration of TMR NDF steadily declined (linear fit, $\mathrm{R}^{2}=0.83, P$ 
$<0.001 ; \mathrm{n}=9)$ from $34.5 \%$ in 2007 to $32.5 \%$ in 2015 (and continued to decline in 2016 to $31.6 \pm 0.17 \%$, data not shown). There was also a clear trend for a decrease (linear fit, $\mathrm{R}^{2}=0.91, P=0.002 ; \mathrm{n}=5$ ) in 24 -h in vitro NDF degradability, from $19.7 \%$ (DM basis) in 2010 to $16.4 \%$ in 2015. On an NDF basis, 24-h NDF degradability decreased from $58.0 \pm 0.13 \%$ in 2010 to 50.6 $\pm 0.10 \%$ in 2015 (data not shown). The decrease in concentration of NDF was accompanied by an increase (linear fit, $\mathrm{R}^{2}=0.49, P=0.02 ; \mathrm{n}=9$ ) in TMR starch concentration, from $22.6 \pm 0.13 \%$ in 2007 to $25.0 \pm$ $0.09 \%$ in 2015 . A similar trend was observed for NFC (from $38.7 \pm 0.11$ to $40.1 \pm 0.10 \%$, for the same period; data not shown). A reflection of the decrease in dietary $\mathrm{CP}$ and increase in starch concentrations was the steady decrease (linear fit, $\mathrm{R}^{2}=0.79, P<0.001 ; \mathrm{n}$ $=9)$ in CP:starch ratio, from $0.73 \pm 0.005$ in 2007 to $0.68 \pm 0.003$ in 2015 .

Despite the clear trends in TMR composition (i.e., decreased CP, increased starch, and decreased CP:starch ratio), MUN concentration could not be related to any dietary variables; it is noted that the feed composition and milk composition data sets were unrelated. Pearson correlation coefficients for average (per year) dietary $\mathrm{CP}$, soluble protein, starch, NDF, and $\mathrm{CP}$ :starch ratio with MUN were low $(\mathrm{r}=-0.17,0.15,-0.31,0.11$, and -0.30 , respectively) and not significant $(P \geq 0.41)$. The correlation analysis could not be performed on a state by year basis because dietary information was not available by state. It is noted that DMI, an important variable that determines milk and milk protein yields (Hristov et al., 2004), was not available for this analysis. If DMI increases on Northeast dairy farms, as reported for research studies by Potts et al. (2017), CP intake may be constant, which will help explain the lack of response in MUN to the trend for decreased TMR CP. A similar lack of relationship between bulk tank MUN from commercial dairies and dietary $\mathrm{CP}$ was reported by Hristov et al. (2015). In a survey of Canadian dairy farms, Fadul-Pacheco et al. (2015) found a relatively low correlation between MUN and dietary CP concentration $(\mathrm{r} \leq 0.24)$ and concluded that MUN is affected by factors other than diet composition and that there is a need to better understand herd characteristics, which may help explain differences in MUN.

Diet composition is only one factor influencing MUN in dairy cows. Feed DMI and intake of CP and protein fractions affect MUN (Lee et al., 2012; Giallongo et al., 2015,2016 ) but these data were not available for the current analysis. Animal factors, such as parity and BW, were also significant predictors of MUN in the analysis of Broderick and Clayton (1997). Non-nutritional factors explained $13 \%$ of the variability in MUN in the study by Arunvipas et al. (2003). Diurnal variation in feed intake and BUN and physiological factors such as labile $\mathrm{N}$ reserves and renal urea reabsorption can also influence MUN (Spek et al., 2013). A considerable between-cow variation in MUN, unrelated to diet, was reported in a recent meta-analysis by Huhtanen et al. (2015).

The clear trends in TMR NDF, starch, and CP: starch ratio may be indicative of increasing inclusion in the diet of cereal grains or corn silage or of increasing starch content of corn silages fed to dairy cows in the Northeast. These trends were accompanied by decreased NDF degradability. Increased dietary starch, through increased inclusion of corn silage or grain, could explain the decreased NDF degradability, as

Table 1. Lactation information, milk yield, and milk composition for northeastern DHIA herds ${ }^{1}$ (source: Dairy Records Management Systems, Raleigh, NC)

\begin{tabular}{|c|c|c|c|c|c|c|}
\hline Year & $\begin{array}{c}\text { Lactation } \\
\text { number }\end{array}$ & $\mathrm{DIM}^{2}$ & Milk yield, $\mathrm{kg} / \mathrm{d}$ & Milk fat, $\%$ & Milk protein,${ }^{3} \%$ & MUN, mg/dL \\
\hline 2004 & $2.3 \pm 0.06$ & $116 \pm 4.0$ & $33.6 \pm 0.42$ & $3.68 \pm 0.032$ & $3.00 \pm 0.012$ & $13.4 \pm 0.15$ \\
\hline 2007 & $2.3 \pm 0.11$ & $186 \pm 4.1$ & $31.1 \pm 0.50$ & $3.89 \pm 0.036$ & $3.15 \pm 0.025$ & $13.7 \pm 0.33$ \\
\hline 2008 & $2.4 \pm 0.03$ & $191 \pm 2.4$ & $31.2 \pm 0.78$ & $3.88 \pm 0.040$ & $3.16 \pm 0.026$ & $13.9 \pm 0.27$ \\
\hline 2009 & $2.3 \pm 0.05$ & $187 \pm 1.8$ & $30.4 \pm 0.79$ & $3.92 \pm 0.031$ & $3.16 \pm 0.025$ & $12.6 \pm 0.22$ \\
\hline 2012 & $2.3 \pm 0.05$ & $178 \pm 2.8$ & $31.4 \pm 0.51$ & $3.86 \pm 0.035$ & $3.12 \pm 0.029$ & $14.3 \pm 0.31$ \\
\hline 2013 & $2.0 \pm 0.14$ & $171 \pm 7.3$ & $32.3 \pm 0.61$ & $3.75 \pm 0.073$ & $3.10 \pm 0.032$ & $14.4 \pm 0.35$ \\
\hline 2014 & $2.2 \pm 0.11$ & $177 \pm 5.1$ & $31.9 \pm 0.55$ & $3.89 \pm 0.025$ & $3.12 \pm 0.013$ & $13.0 \pm 0.32$ \\
\hline 2015 & $2.3 \pm 0.04$ & $180 \pm 1.8$ & $32.4 \pm 0.73$ & $3.90 \pm 0.053$ & $3.12 \pm 0.018$ & $12.2 \pm 0.26$ \\
\hline
\end{tabular}

${ }^{1}$ Data are means $\pm \mathrm{SE}(\mathrm{n}=12$ to 13 states). Within a year, average data for each state were averaged to produce an average for the year. A total of 10,839,461 DHIA records were included in the analysis.

${ }^{2}$ On test day.

${ }^{3}$ Crude or true protein (not specified). 

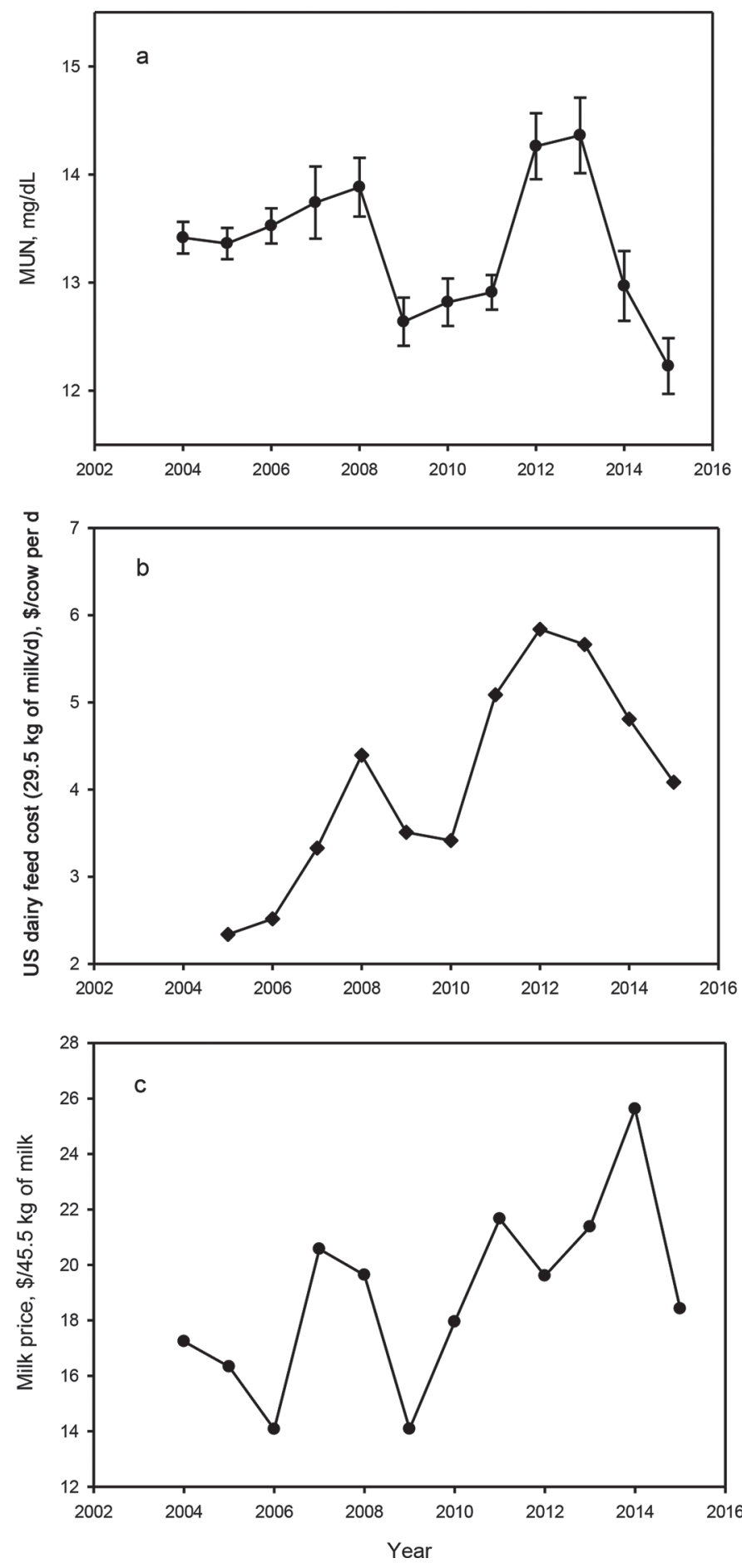

Figure 1. Variability in (a) MUN (error bars are SE; $\mathrm{n}=12$ to 13 states) for DHIA herds in the northeastern United States (source: Dairy Records Management Systems, Raleigh, NC), (b) dairy feed cost (source: University of Wisconsin Dairy Marketing and Risk Management Program at http://future.aae.wisc.edu/data/monthly_ values/by_area/2401?grid=true; accessed Feb. 20, 2017) in the United States, and (c) all milk price in the northeastern United States (source: NASS, 2017) from 2002 to 2015. shown in a meta-analysis by Nousiainen et al. (2009). Corn silage is the main forage in dairy diets in Pennsylvania (Hristov et al., 2015) and the Northeast; as an example, average (2007-2015) corn silage production in the Northeast was about $18.6 \pm 0.32$ million metric tonnes/yr, whereas all alfalfa production (the sum of alfalfa harvested as dry hay, alfalfa haylage, and greenchop production after conversion to a dry equivalent basis) in New York State, Pennsylvania, and Vermont, which produced over $80 \%$ of the alfalfa in the region in 2015 , was $4.3 \pm 0.19$ million metric tonnes/yr (NASS, 2017). Examination of corn silage composition (Dairy One Laboratories, 2017; 2004-2015) showed no visible trends in silage NDF or starch concentrations (average of $43.2 \pm 0.25 \%$ and $32.2 \pm 0.30 \%$, respectively), but 24-h NDF degradability (average: $41.9 \pm 0.99 \%$ ) steadily increased, from $36.5 \%$ in 2004 to $46.6 \%$ in 2015. Thus, corn silage composition does not appear to explain the trends in TMR composition observed in the current analysis. There was no obvious trend in corn silage production in the region (18.5 and 18.4 million metric tonnes/yr in 2007 and 2015, respectively). All alfalfa production in Pennsylvania, New York, and Vermont, however, decreased sharply from 5.1 million metric tonnes/yr in 2007 to 3.7 million metric tonnes/ yr in 2011-2012 and then increased to 3.9 million metric tonnes by 2015 . These trends in corn silage and alfalfa production cannot explain the trends in TMR composition or MUN.

In an effort to explain the observed variability in MUN, we investigated variability in dairy feed cost in Pennsylvania and the United States (Northeast data were not available). Average dairy feed cost in Pennsylvania (for a cow producing $29.5 \mathrm{~kg}$ of milk/d) increased from $\$ 3.08$ in 2005 to $\$ 5.22$ in 2008 , declined to $\$ 4.01$ by 2010 , increased again to $\$ 6.03$ in 2012 , and then declined to $\$ 5.07 / \mathrm{d}$ in 2015. Dairy feed cost for the United States followed similar trends (Figure 1b; $\mathrm{r}=$ $0.95, P<0.001 ; \mathrm{n}=9)$. As expected, feed cost and the all milk price for the Northeast (Figure 1c) generally followed the same trends but were not correlated $(\mathrm{r}=$ 0.46 and $0.50, P>0.17 ; \mathrm{n}=9$ for Pennsylvania and US feed costs, respectively). Correlation between Pennsylvania and United States dairy feed costs and MUN for Northeast dairy farms, however, was high: $\mathrm{r}=0.64$ and $0.71, P=0.06$ and $0.03 ; \mathrm{n}=9$, respectively. There was no correlation between MUN and Northeast milk prices $(\mathrm{r}=0.41, P=0.27 ; \mathrm{n}=9)$. From these data, it appears that high MUN coincided with high feed cost and vice versa. The reason for this association is unclear. It is possible that in years with high feed cost, dairy producers in the Northeast fed higher proportions of alfalfa haylage in lactating cow diets, which led to increased 
Table 2. Dairy TMR composition (DM basis) in the northeastern United States (source: Cumberland Valley Analytical Services, Maugansville, $\mathrm{MD})^{1,2}$

\begin{tabular}{lcccccc}
\hline Year & CP, $\%$ & $\begin{array}{c}\text { Soluble } \\
\text { protein, } \%\end{array}$ & NDF, $\%$ & $\begin{array}{c}\text { 24-h NDF } \\
\text { degradability, } \%\end{array}$ & Starch, \% & CP:starch ratio \\
\hline 2007 & $17.1 \pm 0.06$ & $6.49 \pm 0.06$ & $34.5 \pm 0.13$ & NA $^{3}$ & $22.6 \pm 0.13$ & $0.73 \pm 0.005$ \\
2008 & $17.1 \pm 0.05$ & $6.22 \pm 0.05$ & $34.2 \pm 0.10$ & NA & $22.1 \pm 0.10$ & $0.73 \pm 0.004$ \\
2009 & $16.8 \pm 0.05$ & $6.32 \pm 0.04$ & $33.7 \pm 0.11$ & NA & $24.9 \pm 0.11$ & $0.73 \pm 0.005$ \\
2010 & $16.7 \pm 0.04$ & $5.68 \pm 0.04$ & $33.9 \pm 0.09$ & $19.7 \pm 0.08$ & $24.3 \pm 0.11$ & $0.73 \pm 0.004$ \\
2011 & $16.6 \pm 0.05$ & $6.70 \pm 0.03$ & $34.2 \pm 0.10$ & $19.6 \pm 0.08$ & $24.3 \pm 0.12$ & $0.69 \pm 0.005$ \\
2012 & $16.5 \pm 0.05$ & $6.45 \pm 0.03$ & $33.3 \pm 0.10$ & $18.8 \pm 0.08$ & $24.1 \pm 0.11$ & $0.69 \pm 0.005$ \\
2013 & $16.1 \pm 0.05$ & $6.23 \pm 0.03$ & $33.0 \pm 0.09$ & $16.9 \pm 0.06$ & $24.9 \pm 0.10$ & $0.66 \pm 0.003$ \\
2014 & $16.2 \pm 0.04$ & $6.32 \pm 0.03$ & $32.6 \pm 0.10$ & $16.6 \pm 0.06$ & $24.8 \pm 0.09$ & $0.67 \pm 0.004$ \\
2015 & $16.4 \pm 0.04$ & $6.46 \pm 0.03$ & $32.5 \pm 0.08$ & $16.4 \pm 0.05$ & $25.0 \pm 0.09$ & $0.68 \pm 0.003$ \\
\hline
\end{tabular}

${ }^{1}$ Total mixed ration samples submitted to Cumberland Valley Analytical Services from northeastern states with NDF concentration of 25 to $40 \%, \mathrm{DM}$ basis.

${ }^{2}$ Data are means \pm SE $(\mathrm{n}=3,308$ to 9,707$)$.

${ }^{3} \mathrm{NA}=$ data not available.

MUN concentrations. This hypothesis, however, was not supported by diet chemical composition or annual forage production data.

We conclude from this survey that MUN in Northeast dairy herds between 2004 and 2015 fluctuated without a clear trend or a relationship with dietary $\mathrm{CP}$, soluble protein, starch, NFC, or the ratio CP:starch in an unrelated feed composition data set. It appeared that variability in MUN followed variability in feed cost and milk price. This potential relationship, however, must be interpreted with caution because of the nature of the milk composition versus feed cost databases. Ration ingredient data were not available to better define the reasons for the variations in MUN levels. Examination of the chemical composition of dairy TMR fed in the Northeast showed trends for decreased CP and NDF and increased starch concentrations. This was accompanied by decreased NDF degradability. The trends in TMR composition may be a result of increased inclusion of corn silage or cereal grains in the diet.

\section{ACKNOWLEDGMENTS}

Partial funding for this study was provided by the College of Agricultural Sciences, The Pennsylvania State University.

\section{REFERENCES}

Arunvipas, P., I. R. Dohoo, J. A. VanLeeuwen, and G. P. Keefe. 2003. The effect of non-nutritional factors on milk urea nitrogen levels in dairy cows in Prince Edward Island, Canada. Prev. Vet. Med. 59:83-93.

Broderick, G. A., and M. K. Clayton. 1997. A statistical evaluation of animal and nutritional factors influencing concentrations of milk urea nitrogen. J. Dairy Sci. 80:2964-2971.

Burgos, S. A., N. M. Embertson, Y. Zhao, F. M. Mitloehner, E. J. DePeters, and J. G. Fadel. 2010. Prediction of ammonia emis- sion from dairy cattle manure based on milk urea nitrogen: Relation of milk urea nitrogen to ammonia emissions. J. Dairy Sci. 93:2377-2386.

Castillo, A. R., N. S. del Rio, N. R. St-Pierre, and W. P. Weiss. 2012. Composition of diets fed to different groups of lactating cows on California dairies. J. Dairy Sci. 95(Suppl. 2):360. (Abstr.)

Dairy One Laboratories. 2017. Feed Composition Library. Ithaca, NY. Corn silage: 5/01/2004 to 4/30/2015. Accessed Mar. 3, 2017; http:// dairyone.com/analytical-services/feed-and-forage/feed -composition-library/interactive-feed-composition-library/.

Fadul-Pacheco, L., D. Pellerin, P. Y. Chouinard, M. A. Wattiaux, and E. Charbonneau. 2015. Relationship between milk urea nitrogen and milk protein ratio with dietary and non-dietary variables in commercial dairy herds. J. Dairy Sci. 98(Suppl. 2):746. (Abstr.)

Giallongo, F., M. T. Harper, J. Oh, J. C. Lopes, H. Lapierre, R. A Patton, C. Parys, I. Shinzato, and A. N. Hristov. 2016. Effects of rumen-protected methionine, lysine, and histidine on lactation performance of dairy cows. J. Dairy Sci. 99:4437-4452.

Giallongo, F., A. N. Hristov, J. Oh, T. Frederick, H. Weeks, J. Werner, H. Lapierre, R. A. Patton, A. Gehman, and C. Parys. 2015. Effects of slow-release urea and rumen-protected methionine and histidine on performance of dairy cows fed a metabolizable protein-deficient diet. J. Dairy Sci. 98:3292-3308.

Higgs, R. J., L. E. Chase, and M. E. Van Amburgh. 2012. Application and evaluation of the Cornell Net Carbohydrate and Protein System as a tool to improve nitrogen utilization in commercial dairy herds. Prof. Anim. Sci. 28:370-378.

Hristov, A. N., M. Hanigan, A. Cole, R. Todd, T. A. McAllister, P. M. Ndegwa, and A. Rotz. 2011. Ammonia emissions from dairy farms and beef feedlots: A review. Can. J. Anim. Sci. 91:1-35.

Hristov, A. N., W. Hazen, and J. W. Ellsworth. 2006. Nitrogen, phosphorus, and potassium balance and potentials for reducing phosphorus imports in Idaho dairy farms. J. Dairy Sci. 89:3702-3712.

Hristov, A. N., K. Heyler, E. Schurman, K. Griswold, P. Topper, M. Hile, V. Ishler, E. Wheeler, and S. Dinh. 2015. Reducing dietary protein decreased the ammonia emitting potential of manure from commercial dairy farms. Prof. Anim. Sci. 31:68-79.

Hristov, A. N., W. J. Price, and B. Shafii. 2004. A meta-analysis examining the relationship among dietary factors, dry matter intake, and milk yield and milk protein yield in dairy cows. J. Dairy Sci. 87:2184-2196.

Huhtanen, P., E. H. Cabezas-Garcia, S. J. Krizsan, and K. J. Shingfield. 2015. Evaluation of between-cow variation in milk urea and rumen ammonia nitrogen concentrations and the association with nitrogen utilization and diet digestibility in lactating cows. J. Dairy Sci. 98:3182-3196.

Jenkins, T. C., and M. A. McGuire. 2006. Major advances in nutrition: Impact on milk composition. J. Dairy Sci. 89:1302-1310. 
Jonker, J. S., R. A. Kohn, and R. A. Erdman. 1998. Using milk urea nitrogen to predict nitrogen excretion and utilization efficiency in lactating dairy cows. J. Dairy Sci. 81:2681-2692.

Jonker, J. S., R. A. Kohn, and J. High. 2002. Dairy herd management practices that impact nitrogen utilization efficiency. J. Dairy Sci. $85: 1218-1226$.

Lee, C., A. N. Hristov, T. W. Cassidy, K. S. Heyler, H. Lapierre, G. A. Varga, M. J. de Veth, R. A. Patton, and C. Parys. 2012 Rumen-protected lysine, methionine, and histidine increase milk protein yield in dairy cows fed metabolizable protein-deficient diet. J. Dairy Sci. 95:6042-6056.

Lewis, D. 1957. Blood-urea concentration in relation to protein utilization in the ruminant. J. Agric. Sci. (Camb.) 48:438-446.

NASS (National Agricultural Statistics Service). 2017. National Agricultural Statistics Service, Quick Stats 2.0. Accessed March 7, 2017. https://www.nass.usda.gov/Quick_Stats/.

Nousiainen, J., M. Rinne, and P. Huhtanen. 2009. A meta-analysis of feed digestion in dairy cows. 1. The effects of forage and concentrate factors on total diet digestibility. J. Dairy Sci. 92:5019-5030.

Nousiainen, J., K. J. Shingfield, and P. Huhtanen. 2004. Evaluation of milk urea nitrogen as a diagnostic of protein feeding. J. Dairy Sci. 87:386-398.

NRC. 2001. Nutrient Requirements of Dairy Cattle. 7th rev. ed. Natl. Acad. Sci., Washington, DC.
Potts, S. B., M. Shaughness, and R. A. Erdman. 2017. The decline in digestive efficiency of US dairy cows from 1970 to 2014. J. Dairy Sci. 100:5400-5410

Powell, J. M., C. A. Rotz, and M. A. Wattiaux. 2014. Potential use of milk urea nitrogen to abate atmospheric nitrogen emissions from Wisconsin dairy farms. J. Environ. Qual. 43:1169-1175.

Sova, A. D., S. J. LeBlanc, B. W. McBride, and T. J. DeVries. 2014. Accuracy and precision of total mixed rations fed on commercial dairy farms. J. Dairy Sci. 97:562-571.

Spek, J. W., J. Dijkstra, G. Van Duinkerken, and A. Bannink. 2013. A review of factors influencing milk urea concentration and its relationship with urinary urea excretion in lactating dairy cattle. J. Agric. Sci. (Camb.) 151:407-423.

van Duinkerken, G., M. C. J. Smits, G. André, L. B. J. Šebek, and J. Dijkstra. 2011. Milk urea concentration as an indicator of ammonia emission from dairy cow barn under restricted grazing. J. Dairy Sci. 94:321-335.

Weeks, H. L., T. W. Frederick, L. M. Hagan, K. Heyler, J. Oh, and A. N. Hristov. 2015. Case Study: Farm-level evaluation of implementing nitrogen and phosphorus feeding best management practices on Pennsylvania dairy farms. Prof. Anim. Sci. 31:473-483. 